\title{
Life Cycle Assessment of Using Solar Streetlights for Municipal Streetlighting
}

\author{
Quinn Daigle' ${ }^{1}$ Ijaz Rauf', Paul O'Brien ${ }^{1}$ \\ ${ }^{1}$ York University, Lassonde School of Engineering \\ 4700 Keele St, Toronto, Canada, M3J 1P3 \\ QDaigle@yorku.ca; paul.obrien@ lassonde.yorku.ca \\ ${ }^{2}$ Eminent Tech Consulting \\ 9131 Keele St, Vaughan, Canada, L4K 0G7 \\ irauf@eminent-tech.ca
}

\begin{abstract}
The lifecycle $\mathrm{CO}_{2}$-Eq emissions of solar streetlighting for a subdivision development is analysed and compared with the emissions of grid connected streetlighting. Solar LED streetlighting is shown to offer the potential for the reduction of greenhouse gas emission over grid connected LED streetlighting in areas where the emissions associated with grid electricity generation are greater than $\sim 80 \mathrm{gCO}_{2}$-Eq/kWh. In areas such as Alberta where fossil fuel energy sources provide almost $50 \%$ of the grid electricity generation, solar streetlighting can lead to a $92 \%$ decrease in emissions from streetlighting over a 30-year lifespan.
\end{abstract}

Keywords: Carbon Footprint, Solar Streetlights, Sustainability, $\mathrm{CO}_{2}$ Emissions.

\section{Introduction}

With the increasing need for sustainable development and energy savings, municipalities must examine all systems for increased efficiencies and reduced environmental impacts. Streetlighting is an example of a system that could benefit from improvements, with an estimated $281 \mathrm{TWh}$ of electricity used globally for outdoor lighting [1]. LED streetlighting is already being implemented in various regions such as in Richmond Hill Ontario's outdoor lighting LED conversion project, where 13,000 outdoor lights are being switched to LEDs for energy savings. LED lights consume 50-60\% less electricity and have a longer lifespan than traditional high pressure sodium (HPS) lights [2]. The Richmond Hill conversion project is expected to reduce $\mathrm{CO}_{2}$ greenhouse gas emissions by 300 tonnes per year [2]. Solar powered streetlighting may present an opportunity to further cut costs and reduce the carbon footprint of a municipality. According to an analysis by the company Solar Grid Energy Inc, switching to solar powered streetlights can lead to a $40 \%$ upfront cost savings compared to traditional grid fed lights due to the reduction in trenching, cables, and installation infrastructure. Solar streetlights provide their own power by using a solar PV panel to generate electricity during the day and store it in a battery for use at night. Each streetlight is individually self supporting, eliminating the need to run buried power lines to each light. The battery is generally sized to provide two days of lighting to account for periods of low solar irradiance. In addition to cost and energy savings, solar streetlights can continue to operate during power outages due to independence from the grid. Solar streetlights have an advantage for remote areas where grid energy is unavailable; in contrast, this paper will explore the potential benefits of implementing solar streetlights into municipalities with readily available grid connections by conducting a life cycle assessment (LCA). This LCA study will compare the environmental impacts between using solar streetlighting and gridconnected streetlighting to power the streetlights included in Richmond Hill's outdoor lighting LED conversion project in a small subdivision in Richmond Hill, Ontario.

\section{Scope}

The scope of this study includes a new subdivision development in Richmond Hill, Ontario that utilizes grid connected LED streetlights. The functional unit will thus be road lighting for the entire development. The development has an area of approximately $0.16 \mathrm{~km}^{2}$ and contains 134 streetlights. The study will compare $\mathrm{CO}_{2}$-Eq emissions from grid connected LED streetlights with $\mathrm{CO}_{2}$ emissions from solar powered LED lights for the same development. The grid connected streetlighting 
system will include the lifecycle emissions associated with the manufacturing of the cable and grid energy over the lifespan of the product. The solar powered system will include the life cycle emissions associated with the production of the solar cells and lithium-ion batteries. All other system components are assumed to be constant between both systems and will not be considered. For example, the transformers and the utility trench serve multiple purposes and are required with or without the streetlighting - thus the lifecycle costs for these processes will not be included in the scope of the study. The lifespan of the study is 30 years and it is assumed all general maintenance is the same for both systems. The CML 2001 human toxicity (20 years), acidification, and climate change (20 years) impact categories are evaluated.

\section{Method}

\subsection{Cable Estimates}

Using development plans provided by the Town of Richmond Hill the amount of cable required for the streetlighting was estimated. On average, 59 meters of cable is required per streetlight. This number includes the amount of cable required to run from the transformer to the first light, the spacing of each streetlight and the required cable to run up the height of the streetlight from the buried utility trench. The total length of wire required is $7.5 \mathrm{kms}$. The cable is listed as $2 \mathrm{C}$-\#6 AWG CU RWU90 1000V XLPEI, which was found to have a weight of $328 \mathrm{~kg} / \mathrm{km}$ of wire and a copper content of $232 \mathrm{~kg} / \mathrm{km}$ of wire. The cable is insulated using crosslinked polyethylene, which is assumed to make up the entirety of the mass difference between the wire and the copper mass. This leads to a total wire requirement of $2460 \mathrm{~kg} ; 1740 \mathrm{~kg}$ of copper and $720 \mathrm{~kg}$ of polyethylene. LCA data for Primary copper; at Manufacturer was obtained from publicly available LCAcommons.gov and provided by Yang et al. [3]. The data set provides the amount of copper in terms of its monetary value, in USD, and thus the value of the mass of copper in the wire was also estimated in USD units; this was completed by looking up the price of copper per kg which was found to be $5.87 \mathrm{USD} / \mathrm{kg} \mathrm{Cu}$ [4]. Similarly, LCA data for the polyethylene was obtained from the LCAcommons.gov and provided by the Plastics Division of the ACC; Cradle-to Gate Life Cycle Inventory of Nine Plastic Resins and Four Polyurethane Precursors [5].

\subsection{Electricity Use}

Each streetlight is 21 feet high, weighs $779 \mathrm{lbs}$, and uses a $75 \mathrm{~W}$ LED light, resulting in a total power consumption of $9.75 \mathrm{kWs}$ for the development. Using data from the United States Naval Observatory's Daylight/Darkness Table, it was estimated that there is 4326 hours of darkness and 4434 hours of daylight per year in Toronto, Canada [6]. Using this number as the daylighting hours per year in Richmond Hill, it was estimated that the development uses 42,200 kWh of electricity annually for streetlighting.

\subsection{Solar Cell Estimates}

Environment Canada has published a comprehensive report about the lifecycle GHG emissions from multi-crystalline silicon photovoltaic (Si-PV) cells, providing a compilation of estimates from 5 different papers which averages to 35.25 $\mathrm{gCO} 2-\mathrm{Eq} / \mathrm{kWh}$ [7]. Thus, in this report the lifecycle GHG emissions for multi-crystalline Si-PV solar cells is assumed to be $35.25 \mathrm{~g} \mathrm{CO} 2-\mathrm{Eq} / \mathrm{kWh}$ of electric energy generated. These values are comparable to other values in the literature. For example, Fthenakis et. al. [8] reported that the required energy needed for Si-PV systems is $2400-7600 \mathrm{MJ} / \mathrm{m} 2 \mathrm{with}$ greenhouse emissions in the range of $46-63 \mathrm{gCO} 2-\mathrm{Eq} / \mathrm{kWh}$. Other reports estimate the GHG emissions from multicrystalline $\mathrm{Si}-\mathrm{PV}$ cells to be $40 \mathrm{gCO} 2-\mathrm{Eq} / \mathrm{kWh}$ over their 30 year lifespan [9] [10]. Additional pollution indicators were found to be $80 \mathrm{mg} \mathrm{NO} / \mathrm{kWh}$ and $160 \mathrm{mg} \mathrm{SO} / \mathrm{kWh}[7]$.

\subsection{Lithium-ion Battery Estimates}

The lifecycle impact of lithium-ion batteries was estimated using data found in various papers. Romare et. al. estimate the $\mathrm{CO}_{2}$ emissions to be $150-200 \mathrm{kgCO}_{2-\mathrm{Eq}} / \mathrm{kWh}$ of storage capacity [11] and verify the assumption of linear scaling of emissions per $\mathrm{kWh}$ capacity. Hao et. al. estimate the emissions to be $103 \mathrm{~kg} \mathrm{CO}$-Eq/kWh capacity [12] where as Ellingsen et. al. estimate the emissions to be $96.6 \mathrm{kgCO}_{2}-\mathrm{Eq} / \mathrm{kWh}$ capacity [13]. Averaging out this data gives an emission of $120 \mathrm{~kg}$ $\mathrm{CO}_{2}-\mathrm{Eq} / \mathrm{kWh}$ capacity. Additional values for other impact categories are provided in Table 1.

Lithium-ion batteries degrade to $80 \%$ of their performance after 5000 cycles of operation [13], or 13.7 years of service. The use of the batteries can be extended past this point, and thus for the purposes of this study it will be assumed that the batteries must be replaced every 15 years. The lithium-ion batteries are assumed to be sized such that they will last 24 hours without any charge, and thus must be able to store $1.8 \mathrm{kWh}$. Note the assumption of full power and the exclusion of any 
additional features such as light dimming and light control which would reduce the required battery size or extend the amount of time the light can operate without being charged. Thus, the total required battery storage capacity for this case (referred to as case 1) for the development would be $241 \mathrm{kWh}$ (134 streetlights multiplied by $1.8 \mathrm{kWh}$ per streetlight). Two additional cases are considered to assess the sensitivity of the environmental impacts to the assumption of full lighting power without any dimming capabilities: Case 2, wherein dimming capabilities reduce the battery capacity required for each streetlight to $0.9 \mathrm{kWh}$ with $120 \mathrm{gCO} 2-\mathrm{Eq} / \mathrm{kWh}$ of battery capacity, and Case 3, which is similar to Case 2 but with a more optimistic emissions estimate of $100 \mathrm{gCO} 2-\mathrm{Eq} / \mathrm{kWh}$ of battery capacity.

Table 1: Impacts associated with the production of lithium-ion batteries.

Data provided by [13] L. Ellingsen, B. G.Majeau-Bettez, A. Srivastava, L. Voloen and A. Stromman, "Life Cycle Assessment of Lithium-ion battery Vehicle Pack," J. Ind. Ecol, vol. 18, no. 1, pp. 113-124, 2014.

\begin{tabular}{|c|c|c|}
\hline Fossil Fuel Depletion & 49.5 & $\mathrm{~kg}$ Oil $/ \mathrm{kWh}$ \\
\hline Ozone Depletion & 0.000011 & $\mathrm{~kg} \mathrm{CFC} / \mathrm{kWh}$ \\
\hline Terrestrial Acidification & 1.9 & $\mathrm{~kg} \mathrm{SO} / \mathrm{kWh}$ \\
\hline Freshwater Toxicity & 9.6 & $\mathrm{~kg} 1,4 \mathrm{DCB}-\mathrm{Eq} / \mathrm{kWh}$ \\
\hline human toxicity Potential & 596 & $\mathrm{~kg} 1,4 \mathrm{DCB}-\mathrm{Eq} / \mathrm{kWh}$ \\
\hline Metal Depletion & 154 & $\mathrm{~kg} \mathrm{FE}-\mathrm{Eq} / \mathrm{kWh}$ \\
\hline
\end{tabular}

Deelat sells an 80-watt LED solar streetlight with a lithium-ion battery size of 1298 Wh (DEELAT Solar Streetlight Motion Sensor-Multi-Function with Remote-8000 Lumens LED) [14]. Solar Grid Energy sells a 4000 Lumen solar streetlight with a listed lithium-ion battery capacity of $461 \mathrm{Wh}$ (Product: IP-40) [15]. For a comparable 8000 Lumen light (double the brightness) the battery is assumed to be double the size; $922 \mathrm{Wh}$. These two products provide validation for the estimate of $900 \mathrm{Wh}$ for the battery capacity in the solar streetlight.

In comparison, Deelat also sells a different version of the 80-watt LED solar streetlight that uses a 407 Wh lithium-ion battery, (DEELAT solar powered streetlight - 10000 Lumens LED - 21776409) [14]. It is speculated that this light is designed for applications where the light is able to operate on low power settings for the majority of its use. Dimming of streetlight systems has been implemented in large scale European systems with the expectation of reducing energy use by 30- 50\% [16]. Marino [17] reported an estimated energy savings of 30\% for streetlighting systems that use dimming control.

\subsection{Electricity}

Several different sources of electricity were examined. Ontario Grid electricity was found to emit $39 \mathrm{gCO} 2-\mathrm{Eq} / \mathrm{kWh}$ based on data from Ontario Power Generation [18]. Ontario has exceptionally low greenhouse gas emissions from electricity due to large amounts of hydro and nuclear power, however some provinces in the country emit as much as $790 \mathrm{gCO} 2-$ eq/kWh, with a national average of $140 \mathrm{gCO} 2-\mathrm{Eq} / \mathrm{kWh}$ [19]. The Canadian grid emissions were established by using the electricity generation split from Canada's Renewable Power Landscape 2017 [19] and linking the required process with providers in OpenLCA. Additionally, LCA databases for Electricity, at Grid, US 2010 [20], obtained from LCACommons.gov was used for comparison in the US.

\subsection{High Pressure Sodium Streetlighting Comparison}

Although this study is comparing LED grid connected streetlighting with LED solar streetlights, it is worth noting most streetlights use HPS lighting [2]. HPS lights use 40-50\% more electricity than LED lights to produce the same amount of light [2]. A comparison case has been added to compare HPS lighting by increasing the calculated amount of electricity by $50 \%$ to represent the HPS grid connected lighting.

\subsection{Software}

OpenLCA was used to compile the various LCA databases and apply the CML 2001 impact assessment method. 


\section{Results}

Error! Reference source not found. shows a summary of the results attained using OpenLCA software. A few different cases for the grid connected streetlights are presented which isolated impacts of the copper cabling, and shows the impact of various $\mathrm{gCO} 2-\mathrm{Eq} / \mathrm{kWh}$ values from different grid electricity sources. Cases 1-3 are further broken down into contributing components in Error! Reference source not found.

Table 2: CML 2001 impact category indicators

\begin{tabular}{|c|c|c|c|}
\hline Case & $\begin{array}{l}\text { Human Toxicity } \\
\text { (HTP 20a) } \\
\text { (kg 1,4-DCB-Eq) }\end{array}$ & $\begin{array}{l}\text { Acidification Potential } \\
\text { (general) } \\
\left(\mathrm{kg} \mathrm{SO}_{2}-\mathrm{Eq}\right)\end{array}$ & $\begin{array}{l}\text { Climate Change } \\
\text { (GWP 20a) } \\
\left(\mathrm{kg} \mathrm{CO}_{2}-\mathrm{Eq}\right)\end{array}$ \\
\hline $\begin{array}{l}\text { Grid connected streetlighting with electricity from the US } \\
\text { Electrical Grid avg (no copper) }\end{array}$ & 45,000 & 5,600 & 61,889 \\
\hline $\begin{array}{l}\text { Grid connected streetlighting with electricity from US } \\
\text { Electrical Grid avg }\end{array}$ & 50,100 & 5,600 & 62,140 \\
\hline $\begin{array}{l}\text { Grid connected streetlighting with electricity from } \\
\text { Canadian Average }\left(140 \mathrm{gCO}_{2}-\mathrm{Eq} / \mathrm{kWh}\right)\end{array}$ & 5,180 & 92 & 177,000 \\
\hline $\begin{array}{l}\text { Grid connected streetlighting with electricity from US } \\
\text { Electrical Grid }\left(60 \mathrm{gCO}_{2}-\mathrm{Eq} / \mathrm{kWh}\right)\end{array}$ & 50,100 & 5,600 & 76,380 \\
\hline $\begin{array}{l}\text { Case 1: Solar LED streetlighting ( } 1800 \mathrm{Wh}, 120 \mathrm{gCO}_{2^{-}} \\
\mathrm{Eq} / \mathrm{kWh})\end{array}$ & 226 & 1,160 & 102,440 \\
\hline $\begin{array}{l}\text { Case 2: Solar LED streetlighting }\left(900 \mathrm{Wh}, 120 \mathrm{gCO}_{2^{-}}\right. \\
\mathrm{Eq} / \mathrm{kWh})\end{array}$ & 182 & 706 & 73,500 \\
\hline $\begin{array}{l}\text { Case 3: Solar LED streetlighting }\left(900 \mathrm{Wh}, 120 \mathrm{gCO}_{2^{-}}\right. \\
\text {Eq/kWh) }\end{array}$ & 182 & 706 & 68,700 \\
\hline
\end{tabular}

Table 3: Detailed break-down of LED streetlight emissions for Cases 1, 2 and 3

\begin{tabular}{|l|c|c|}
\hline Case 1 (worst case) & Amount $\left(\mathrm{gCO}_{2}-\mathrm{Eq} / \mathrm{kWh}\right)$ & $\%$ \\
\hline Solar cells & 44920 & $43.7 \%$ \\
\hline Li ion batteries & 57840 & $56.3 \%$ \\
\hline Total & 102760 & \\
\hline Case 2 (Moderate Case) & & $60.8 \%$ \\
\hline Solar cells & 44920 & $39.2 \%$ \\
\hline Li ion batteries & 28920 & \\
\hline Total & 73840 & $65.1 \%$ \\
\hline Case 3 (Best case) & & $34.9 \%$ \\
\hline Solar cells & 44920 & \\
\hline Li ion batteries & 24100 & \\
\hline Total & 69020 & \\
\hline
\end{tabular}

\section{Discussion}

From an environmental standpoint, based on the global warming indicator, the decision to use solar streetlights with battery storage or to use grid connected streetlighting comes down to the amount of CO2-Eq emitted while generating grid electricity compared to the CO2-Eq emissions associated with manufacturing the photovoltaic cells and batteries required for solar street lighting. For example, manufacturing the amount of copper cabling required would produce 8,700 kg CO2Eq emissions, which represents $1 \%$ and $14.7 \%$ of the global warming potential impact when the streetlights are connected to the grid in the USA and Ontario, respectively. Error! Reference source not found. shows the results from the three different solar powered lighting cases considered (Case 1: the worst case, Case 2: a moderate case, and Case 3: the best case) and the lifecycle $\mathrm{CO} 2-\mathrm{Eq}$ emissions for the streetlights plotted as a function of the electric power generation emission factor (in units of $\mathrm{gCO} 2-\mathrm{Eq} / \mathrm{kWh}$ ). Markers for the emissions produced in each Canadian province are included and can be used to determine the advantages of implementing solar streetlights based on grid emissions. 


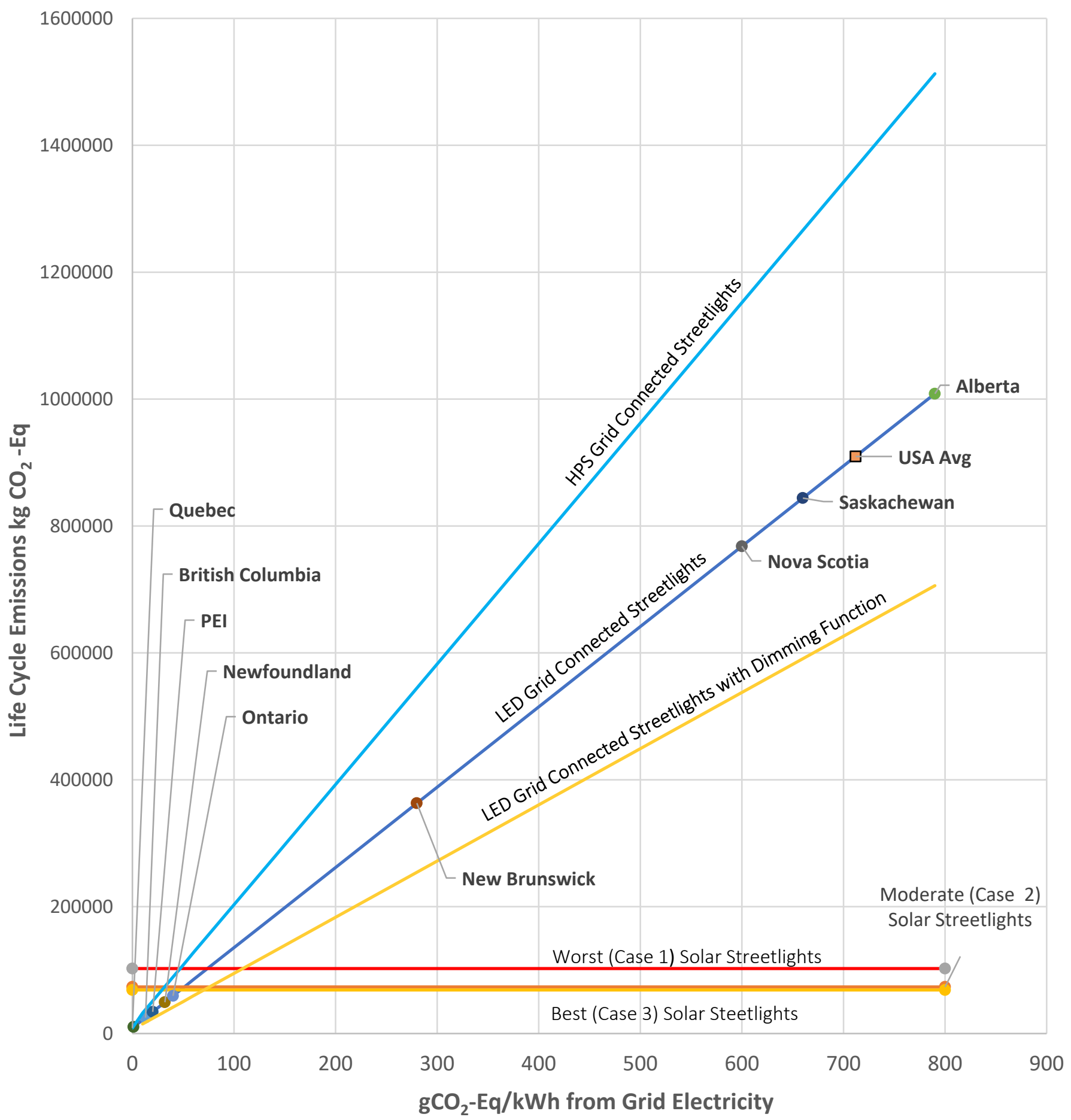

Fig 1: Emissions produced by streetlights over their lifespan with electricity sourced from different regions.

Source for $\mathrm{CO}_{2}$ emissions per province from “Canada's Renewable Energy Landscape 2017. National Energy Board" [19] **note that the horizontal lines indicate the fixed $\mathrm{CO}_{2}$-Eq emissions of the solar Streetlights.Error! Reference source not found. 
For the cases wherein the streetlights are assumed to have dimming capabilities (Cases 2 and 3), the results in Figure 1 show that using LED solar streetlights reduces $\mathrm{CO}_{2}$-Eq emissions when generating grid electricity produces more than 80 $\mathrm{gCO}_{2}-\mathrm{Eq} / \mathrm{kWh}$ as compared to grid-connected LED lighting that uses light dimming strategies. Considering streetlights without dimming capabilities, for Case 1 (the worst-case scenario where no dimming is used, and $1800 \mathrm{~W}$-h batteries are required for the solar streetlights) using LED solar streetlights reduces $\mathrm{CO}_{2}$-Eq emissions when generating grid electricity produces more than $\sim 75 \mathrm{gCO}_{2}-\mathrm{Eq} / \mathrm{kWh}$.

The results shown in Figure 1 reveal that the use of solar streetlights must be analysed on a case by case basis depending on the local grid electricity mix. In Ontario, due to the low $\mathrm{CO}_{2}$ emissions associated with grid electricity generation, the use of solar streetlights is not recommended; However, they provide value to other provinces or countries with higher grid emissions - such as Alberta, USA, New Brunswick, Nova Scotia and Saskatchewan. Furthermore, it can also be seen in Figure 1 that the additional electrical needs of using HPS lighting causes an increase of between $40 \%$ (for low emitting electrical grids) to $50 \%$ (for high emitting electrical grids) in the amount of $\mathrm{CO}_{2}$ emitted from the lighting system over its lifespan - thus switching to LED bulbs or to Solar LED Lighting are both beneficial as compared to HPS lighting. That is, in comparison to HPS lighting solar LED streetlights become a viable way to reduce $\mathrm{CO}_{2}$ emissions in regions where electric grids produce more than 31, 33 and $50 \mathrm{gCO}_{2}-\mathrm{Eq} / \mathrm{kWh}$, for the best case (Case 3), moderate case (Case 2) and worst-case (Case 1) scenarios, respectively. Error! Reference source not found. shows that for the solar streetlights, the solar cells have a higher impact than the batteries for the best and moderate cases. Furthermore, additional analysis reveals that a $15 \%$ reduction in $\mathrm{CO}_{2}$-Eq emissions from solar cell production results in a $6640 \mathrm{kgCO}_{2}-\mathrm{Eq}(9.6 \%)$ reduction whereas a $20 \%$ reduction in $\mathrm{CO}_{2}$-Eq emissions from battery production results in a $4800 \mathrm{kgCO}_{2}-\mathrm{Eq}(6.5 \%)$ reduction in $\mathrm{CO}_{2}-\mathrm{Eq}$ emissions. A $50 \%$ reduction in battery capacity (from $1800 \mathrm{kWh}$ to $900 \mathrm{kWh}$ ) results in a $28,950 \mathrm{kgCO}_{2}$-Eq $(28 \%)$ reduction.

For the grid connected streetlighting, the $\mathrm{CO}_{2}$-Eq emissions associated with the copper cabling has minor impact on the overall results, accounting for $8689 \mathrm{~kg}(1 \%)$ of the $\mathrm{CO}_{2}$-Eq emissions when using electricity from the US electrical grid and $14.6 \%$ of the emissions when using the Ontario grid. Improvements in solar cells and battery performance may further improve the case for solar streetlights by reducing the associated $\mathrm{CO}_{2}$-Eq emissions from the manufacturing process. An alternative method to reduce greenhouse gas emissions related to streetlighting would be to improve the electrical grid supply by implementing renewable technologies - such as by building a dedicated solar array that feeds directly into the electrical grid in order to offset the electricity needs of the lighting system.

\subsection{Notes on Study Accuracy}

Due to limited availability and content of LCA databases, data was collected from various published works. Due to the rapid change in technology for both solar cells and lithium-ion batteries, more recent LCA data would improve the accuracy of the study. Transportation of components to build and install the cables, batteries and PV cells was generally excluded from the scope of the study. Calculations showed that the effect of transporting all 2.5 tons of copper wire over $1000 \mathrm{~km}$ by truck had less than a $0.1 \%$ effect on overall emissions, thus justifying its removal from the scope.

\section{Conclusion}

Solar streetlights can reduce emissions related to streetlighting by $92 \%$ when integrated into grids with high emissions such as in Alberta. The main factors found to influence of grid connected streetlighting was the amount of emissions produced per kWh of electricity generated. Implementation of solar streetlights for emission reduction purposes should be done on a case by case basis that examines the local electrical grid for the project. For solar streetlights, the main factors influencing the overall emissions are the amount of $\mathrm{CO}_{2}$-Eq produced by manufacturing solar cells, followed by the required capacity of the battery storage and emissions related to the lithium-ion battery manufacturing. The cabling for grid connected streetlighting was shown to have minimal impact on the life cycle impacts of a streetlighting system.

\section{Acknowledgements}

The authors are grateful for support provided by the Natural Sciences and Engineering Council of Canada. 


\section{References}

[1] I. Rauf, The Case for Green Street Lights: It Is Cheaper than Traditional Street lights, LinkenIn, 2017.

[2] Richmond HIll, "Outdoor Lighting LED Conversion Project," Richmond Hill, 2019. [Online]. Available: https://www.richmondhill.ca/en/find-or-learn-about/outdoor-lighting-led-conversion-project-.aspx.

[3] Y. Yang, Ingwersen and Hawkins, "USEEIO: A new and transparent United States environmentally-extended inputoutput model," Journal of Cleaner Production, 2017.

[4] "Copper Prices - 45 year historical chart," macrotrends LLC, 2019. [Online]. Available: https://www.macrotrends.net/1476/copper-prices-historical-chart-data.

[5] "Polythylene terephthalate, resin, at plant, CTR," LCAcommons, [Online]. Available: https://www.lcacommons.gov/lca-

collaboration/National_Renewable_Energy_Laboratory/USLCI/dataset/PROCESS/e4822728-95ae-3360-9870c363a214611e.

[6] "Durration of Daylight/Darkness Table for one Year," USNO, $2907 \quad 2015 . \quad$ [Online]. Available: https://aa.usno.navy.mil/data/docs/Dur_OneYear.php.

[7] Assessment of the Environmental Performance of Solar Photovoltaic Technologies, Environment Canada, 2010.

[8] V. Fthenakis and H. Kim, "Photovoltaics: Life-cycle analyses," Sol. Energy, vol. 85, no. 8, pp. 1609-1628, 2011.

[9] G. a. D.Sandor, "Life Cycle Greenhouse Gas Emissions from Solar Photovoltaics (Fact Sheet)," NREL, 2012.

[10] D. H. e. al., "Life Cycle Greenhouse Gas Emissions of Crystalline Silicon Photovoltaics Electricity Generatio: Systematic Review and Harmonization," J. Ind. Ecol, vol. 16, 2012.

[11] M. Romare and L. Dahllöf, 2017. "The Life Cycle Energy Consumption and Greenhouse Gas Emissions from lithiumion Batteries" IVL Swedish Environmental Research Institute, 2017.

[12] H.Hao, Z.Mu, S.Jiang, Z. Liu and F. Zhao, "GHG Emissions from the production of Lithium-ion batteries for electric vehicles in China," Sustain, vol. 9, no. 4, 2019.

[13] L. Ellingsen, B. G.Majeau-Bettez, A. Srivastava, L. Voloen and A. Stromman, "Life Cycle Assessment of Lithium-ion Battery Vehicle Pack," J. Ind. Ecol, vol. 18, no. 1, pp. 113-124, 2014.

[14] "DeeLat Solar Street Lights," DeeLat, 2019. [Online]. Available: https://www.deelat.ca/solar-lighting-andproducts/solar-street-lights/?gclid=CjwKCAjwg-DpBRBbEiwAEV1_-

DIaQM8dlKCDiConqdEF1zkxprWJLaEvLpcNPMqe9wwwQmwemi3EfBoCfAgQAvD_BwE. [Accessed 2407 2019].

[15] "Solar Street Light," Solar Grid Energy, 2019. [Online]. Available: http://www.solargridenergy.ca/productsservices/solar-street-light/.

[16] M. Hanlol, "OSLA to cut streetlight Energy Costs by 30\% while increasing safety," 76 2006. [Online]. Available: https://newatlas.com/go/5475/.

[17] F. Marino, "Adaptive Street Lighting Predictive Control," Science Direct, vol. 111, pp. 790-799, 2017.

[18] Intrinsik Corp, "Greenhouse Gas Emissions Associated with Various methods of Power Generation in Ontario," 2016.

[19] "Canada's Renewable Power Lanscape 2017," National Energy Board, 2017. [Online]. Available: https://www.nebone.gc.ca/nrg/sttstc/lctrct/rprt/2017cndrnwblpwr/cndnvrvw-eng.html.

[20] "Electrcity, at Grid, US, 2010.," LCA commons , 2010. [Online]. Available: https://www.lcacommons.gov/lcacollaboration/National_Renewable_Energy_Laboratory/USLCI/dataset/PROCESS/89389d98-1ba6-30c5-9c3392443694936b. 